ENTREPRENEURSHIP AND SUSTAINABILITY ISSUES

ISSN 2345-0282 (online) http://jssidoi.org/jesi/

2020 Volume 8 Number 1 (September)

http://doi.org/10.9770/jesi.2020.8.1(7)

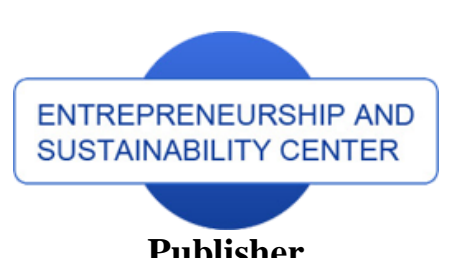

Publisher

http://jssidoi.org/esc/home enterprise europe network

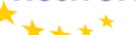

Business Support on Your Doorstep
Scopus

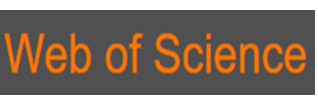

1) Clarivate Analytics

\title{
TOWARD THE BEST PRACTICE EMISSIONS REDUCTION IN AN EMERGING ECONOMY: AN ANALYSIS OF CEMENT MANUFACTURING IN INDONESIA*
}

\author{
Togar W. S. Panjaitan ${ }^{1}$, Paul Dargusch ${ }^{2}$, David Wadley ${ }^{3}$, Ammar A. Aziz ${ }^{4}$ \\ ${ }^{1,2,3}$ School of Earth and Environmental Sciences, University of Queensland, Brisbane, Brisbane St Lucia, QLD 4072, \\ Australia \\ ${ }^{1}$ Industrial Engineering Department, Petra Christian University, Surabaya, 121-131 Siwalankerto, Surabaya, Jawa Timur \\ 60236, Indonesia \\ ${ }^{4}$ School of Agriculture and Food Sciences, University of Queensland, Gatton, Gatton QLD 4343, Australia \\ E-mails: ${ }^{1}$ tw.soaloon@uq.edu.au; ${ }^{2}$ p.dargusch@uq.edu.au; ${ }^{3}$ d.wadley@uq.edu.au; ${ }^{4}$ a.abdulaziz@uq.edu.au
}

Received 10 January 2020; accepted 20 June 2020; published 30 September 2020

\begin{abstract}
Cement manufacturing is an energy-and carbon-intensive process and a prominent contributor to global anthropogenic greenhouse gases (GHGs). Within emerging economies, this industry's considerable potential to pollute can be exacerbated by outmoded plant or practices, and management's limited capacity to remediate. In this context, the current study analyses the case of Indonesia's leading producer, recording variations in greenhouse gas (GHG) sources to pinpoint opportunities for reduction. Emissions, measured $20 \%$ higher than the 2030 global industry target, occur from the calcination process, abetted by fuel combustion. Reductions should be focused on reducing the clinker-to-cement ratio and promoting the uptake of alternative fuels. Avenues lie in increasing the use of clinker substitutes such as fly ash and limestone, and employing fuels derived from waste and biomass. Both sources are abundant in Indonesia. Further declines in GHGs could be achieved through technological innovations such as the upgrading of kilns. The inquiry provides recommendations for emission mitigation in the cement industry not only in Indonesia but also in other developing countries.
\end{abstract}

Keywords: emission intensity, reductions, clinker substitutes, alternative fuels, kilns

Reference to this paper should be made as follows: Panjaitan, T. W. S., Dargusch, P.; Wadley, D., Ammar, A. A. 2020. Toward the best practice emissions reduction in an emerging economy: An analysis of cement manufacturing in Indonesia. Entrepreneurship and Sustainability Issues, 8(1), 103-122. http://doi.org/10.9770/jesi.2020.8.1(7)

JEL Classifications: L61, O14, Q56

\footnotetext{
* This research is supported by SEES, the University of Queensland and the Ministry of Research, Technology and Higher Education - Republic of Indonesia together with the Indonesian Endowment Fund for Education (LPDP) - Ministry of Finance - Republic of Indonesia under BUDI LN (2017-2020) for postgraduate study, Grant Agreement Number 20160822028916.
} 


\section{ENTREPRENEURSHIP AND SUSTAINABILITY ISSUES}

ISSN 2345-0282 (online) http://jssidoi.org/jesi/

2020 Volume 8 Number 1 (September)

http://doi.org/10.9770/jesi.2020.8.1(7)

\section{Introduction}

Emerging economies can be significant contributors to global GHG growth (Olhoff \& Christensen, 2018). Indonesia, as part of that grouping, is rated as the world's eighth largest emitter in absolute terms, though GHG output per capita only ranks 100th. By 2030, the national government is committed, through domestic funding, to reduce 29\% of emissions based on 2000 levels (Janssens-Maenhout et al., 2017; Dasih \& Widodo, 2019). Energy use is one of the priorities, together with control of forest fires and peatland degradation (Haryanto \& Martawardaya, 2015). Approximately one-third of GHGs from energy consumption comes from the industrial sector (BPPT, 2016). It has been prioritized for emission mitigation by the government, especially in stronglycontributing industries such as cement, iron and steel, and paper (Iklim, 2010; Ke et al., 2012). Cement-making is the most significant of these fields, accounting for $20 \%$ of national total manufacturing GHGs, specifically $\mathrm{CO}_{2}$ (Panjaitan et al., 2018). It consumes about $7 \%$ of the total energy supplied in Indonesia, comprising nearly $40 \%$ of its total production costs (Haryanto \& Martawardaya, 2015; Panjaitan et al., 2018). Coal is the focus and usage had risen from 10.54 million in 2010 to 16.16 million tons in 2018 (Ali et al., 2011; Ke et al., 2012; Haryadi \& Suciyanti, 2018). This increase is driven by the growing demand for cement, resulting from economic growth and the continued effort to provide adequate infrastructure in the country (Iklim, 2010; Ke et al., 2012). It is estimated that the industry's emissions will quadruple by 2030 compared with the 2005 level (Iklim, 2010; Ke et al., 2012; Olivier et al., 2017). As a consequence, it has been prioritized for attention by the Government (BPPT, 2016).

Studies have been conducted to examine the potential for emission reduction in the global cement industry (Hasanbeigi et al., 2010a; Iklim, 2010; Ali et al., 2011; Ke et al., 2012). The International Energy Agency (IEA) concentrates on four measures, namely, improving thermal and electric efficiency by adopting state-of-the-art technologies, encouraging clinker substitution, using alternative fuels (AFs) which have lower carbon impact or are carbon-neutral, and involving carbon capture storage (CCS) technology (WBCSD-IEA, 2009). Investigations from an engineering technology perspective are becoming more numerous (WBCSD-IEA, 2009; IEA, 2017). Yet, most measures are capital intensive and pose inherent difficulties in a developing economy. Accordingly, industry has limited funds for improvements to achieve anything near world best practice (Haryanto \& Martawardaya, 2015; Panjaitan et al., 2018).

Grubler (2012) states that policies or strategies applied in developed countries should not be directly translated to developing ones. It is important to realize that the transition will not always produce the same results if implemented elsewhere. In general, the existing process is probably uniform, but the exact mechanism of change is not understood. Therefore, policy-making needs to consider local conditions which usually have different factors influencing abatement options.

Several issues bear upon the industry's willingness to reduce its emissions. Financial gain or cost savings (e.g. products with lower cost and better quality compared with competitors) are dominant influences in adopting changes or innovations (Okereke, 2007; Urbancova, 2013), followed by complying with regulations, market demand, and moral/social concerns (Tsitsiragos, 2016). An overarching inquiry is needed to provide a framework for reducing emissions that is suitable for the conditions of the cement industry in Indonesia. It begins by presenting a GHG emissions inventory from the case study company in Indonesia, leading to identification of ways to foster mitigation.

Given this background, the present inquiry aims to chart the potential for energy reform and emission reduction in the Indonesian cement industry. Taking a case study approach, it assesses the environmental performance of the country's leading producer, which operates a series of plants across the archipelago and accounts for about twothirds of the market (Board, 2019). Conscious of the operating constraints mentioned, the work evaluates the local opportunity to establish appropriate mitigation measures. The findings could assist other nations, which experience manufacturing conditions similar to those in Indonesia. 


\section{ENTREPRENEURSHIP AND SUSTAINABILITY ISSUES}

ISSN 2345-0282 (online) http://jssidoi.org/jesi/ 2020 Volume 8 Number 1 (September) http://doi.org/10.9770/jesi.2020.8.1(7)

\section{Cement Production}

Cement is a primary building material for infrastructure. Remarkably, this industry, viewed globally, produces around 5\% of all human-made GHGs (WBCSD-IEA, 2009; Haraguchi et al., 2017). Strategic steps are required in carbon management to reduce pollution. The impetus is not only to meet government and international targets but also to improve competitiveness, enhance economic and social values and ensure a better environment.

Cement manufacturing falls into wet and dry modes. In the wet process, water is added to the raw materials to form a slurry, while the dry method prepares a fine powder by grinding and drying such inputs. It is the less energy intensive means, because the wet method needs extra heat input to remove moisture in the slurry (Ke et al., 2012).

The production process can be divided into the preparation of raw materials, followed by clinker and cement making (Figure 1) (Afkhami et al., 2015; Panjaitan et al., 2018). The basic ingredients, such as limestone, clay and correction materials, are crushed and ground to produce raw meal. A crusher is needed for crushing, while a roller mill grinds the mixture. To this point, mechanical force is paramount, powered by equipment which uses electricity supplied from outside the plant. Next comes the most energy-intensive process, clinker making. It starts with pre-heating to eliminate water content by utilizing hot gas from a kiln. The products move on to the heat- and emissions-intensive calcination stage in a rotating kiln to produce clinker. They will then undergo rapid cooling using air exchange. The resulting clinker is mixed with additives to produce cement (WBCSD-IEA, 2009; Afkhami et al., 2015; Panjaitan et al., 2018).

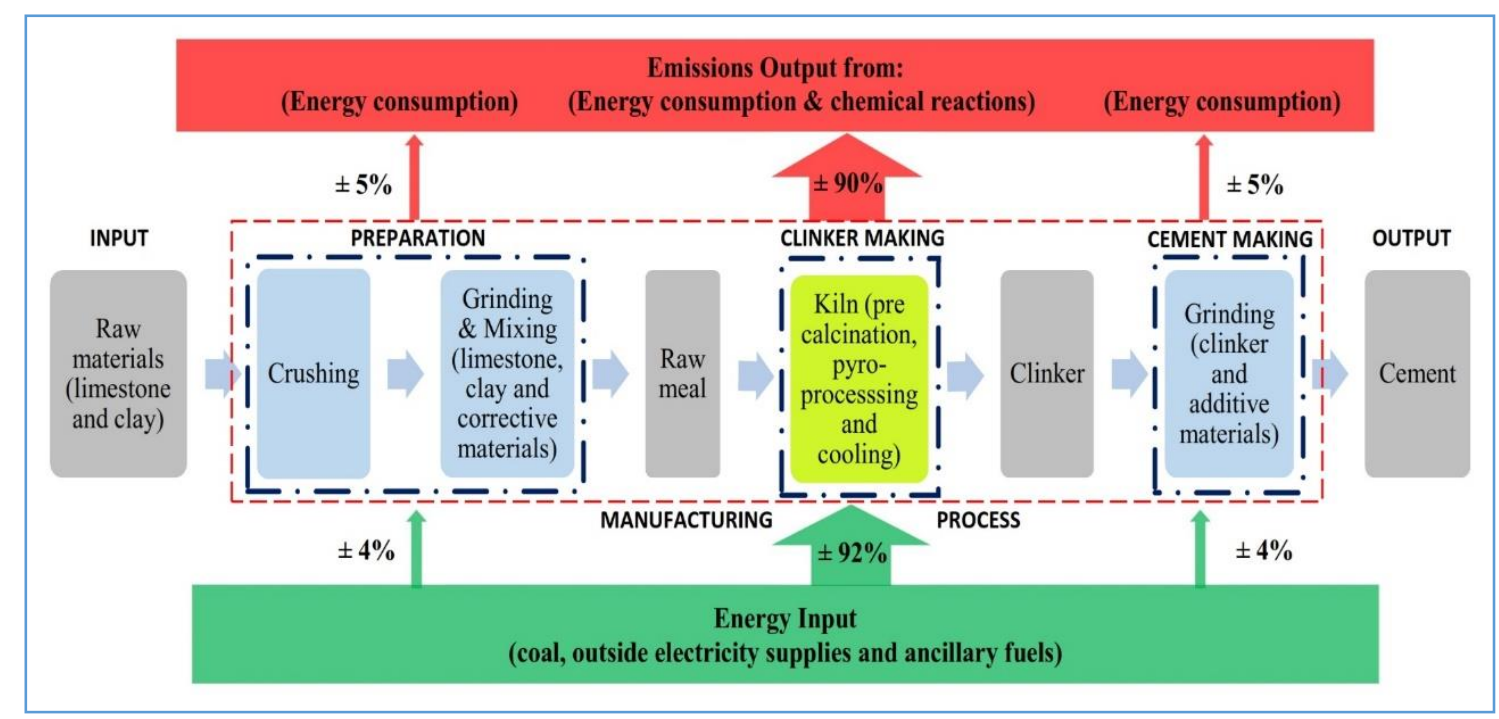

Fig. 1. The process of cement production

Source: Authors, based on (WBCSD-IEA, 2009; Galvez-Martos \& Schoenberger, 2014; Afkhami et al., 2015; Stafford et al., 2016)

\section{Computational Methods}

The Indonesian government has set out its Minister of Industry Regulation No. 12/2012, which governs the reduction of cement emissions and has quantitative targets. However, it has not been followed by a scheme offering rewards for reaching goals or, otherwise, penalties. Some developed countries have implemented a carbon tax policy to encourage the use of alternative energy by making it cost-competitive with cheaper fuels. The Indonesian government has not yet implemented such a tax because it is concerned that it will reduce the 


\section{ENTREPRENEURSHIP AND SUSTAINABILITY ISSUES}

ISSN 2345-0282 (online) http://jssidoi.org/jesi/ 2020 Volume 8 Number 1 (September) http://doi.org/10.9770/jesi.2020.8.1(7)

performance of industries, which are essential contributors to state revenues. The economic and political environment in the nation is such that taxes or strict controls on the sector are ineffective or even impractical in seeking mitigation measures. A comprehensive study is required to find out how to incentivize companies to reduce emissions voluntarily.

An appropriate strategy is also needed in managing carbon to produce attractive and feasible abatement options for decision-makers. The study begins by taking an emissions inventory within the cement production process. It will lead to the identification and implementation of ways to foster mitigation. We collect and analyze data to examine the sources and amounts of emissions in the overall context of environmental performance. The abatement projections are derived by comparing inventory results with key indicators to achieve sustainability in the global cement industry, adjusting for local conditions. The paper does not discuss microeconomic issues but, instead, focuses on the practical reality of the cement industry in Indonesia. It is part of a comprehensive investigation that will result in a broader collection of studies, which will examine the potential for emission reductions and costs, and the response of management to emission reduction options.

Compared with developed countries, emerging economies have limited access to capital and lack the knowledge, public acceptance and government support to reduce emissions (WBCSD-IEA, 2009; Iizuka, 2015). Their advanced counterparts have pioneered solutions in the cement industry by adopting the latest aids, such as stateof-the-art kiln technology and CCS (Jordal et al., 2017; Nabernegg et al., 2017). These approaches complement the use of alternative fuels (AFs) (e.g., tires and industrial waste) (WBCSD-IEA, 2009; Bakhtyar et al., 2017). With this backdrop, we analyze the operations of the leading cement company in Indonesia with a view to reforming energy sources and targeting emission reduction.

\subsection{Guidelines for Calculating and Reporting GHG Emissions}

An initial issue is to examine and measure the sources of GHGs in cement production (Galvez-Martos \& Schoenberger, 2014; Feiz et al., 2015). The Cement Sustainable Initiative (CSI)-World Business Council for Sustainable Development (WBCSD) has issued harmonized guidelines for monitoring performance, reporting, and calculating emissions for the industry worldwide (WBCSD, 2011; Geng et al., 2019).

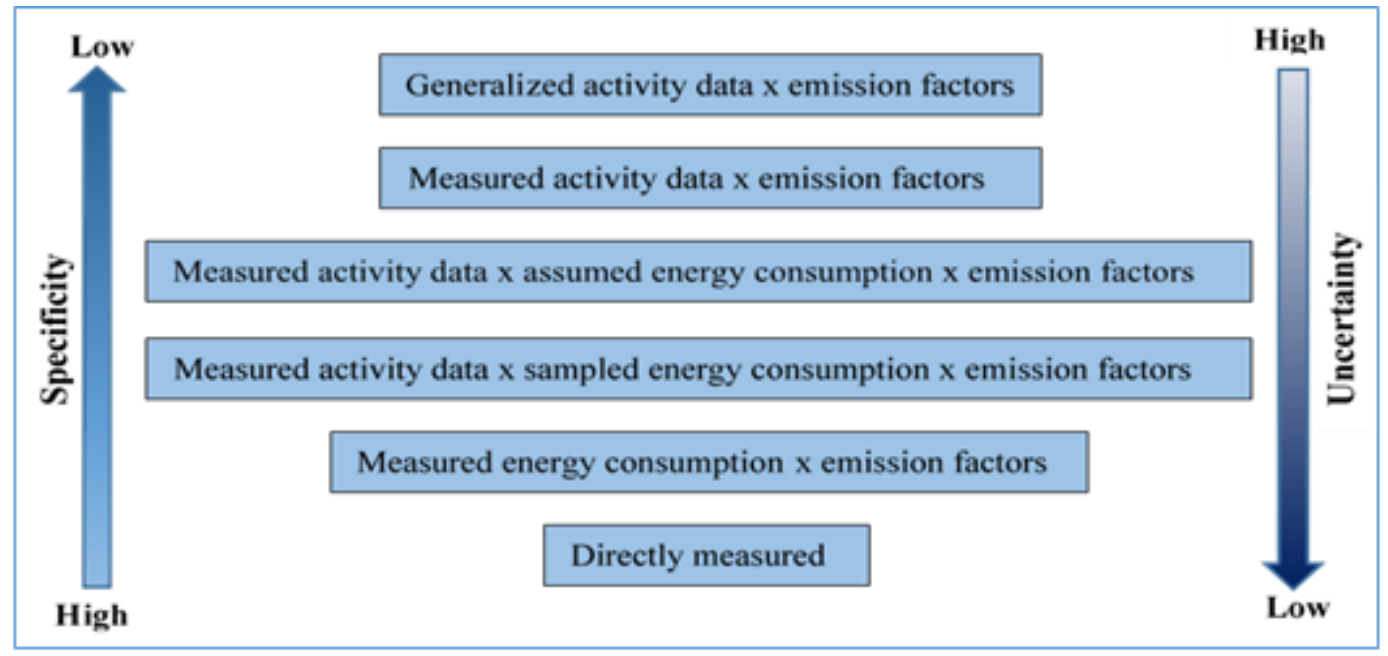

Fig. 1. Emissions measurement methods

Source: (Wright et al., 2011; Williams et al., 2012) 
Operating in about 100 countries, the CSI is a program of the WBCSD. It aims to develop management guidance and minimize the impact of cement production by addressing various issues to do with production inputs and outputs. The Initiative also provides accurate and detailed data that enable the industry to identify factors and levers that can influence emissions and develop practical climate mitigation strategies.

Andrew (2018) states that calculating emission intensity in the Indonesian setting often encounters problems caused by inconsistencies in the figures. The method used will be determined by the availability of specific information. Data provide different levels of specificity and uncertainty, as outlined in Figure 2 and the points below (Burritt et al., 2011; Wright et al., 2011; Society, 2012):

- Use of non-specific data such as the national average energy consumption and Intergovernmental Panel on Climate Change (IPCC) default emissions factors have the highest level of uncertainty and a low level of specificity.

- Use of specific data such as estimating the amount of fuel consumption from purchase costs in a year and using country/technology-specific emission factors will increase specificity and reduce the uncertainty involved.

- Use of technology-specific data or direct measurement has the least uncertainty but requires a high level of specificity, requiring, for example, a direct measure of energy consumption and emissions, and analysis of equipment based on design specifications, age, and maintenance.

Establishing operational limits is the priority in framing the emissions inventory. It is calibrated by "scope", which relates to the sources of direct and indirect emissions as per Table 1.

Table 1. The sources of emissions

\begin{tabular}{|c|c|c|}
\hline Emission & Definition & Sources \\
\hline Scope 1 & $\begin{array}{l}\text { Direct emissions occur from sources that are owned/ or } \\
\text { controlled by the company. }\end{array}$ & Combustion in boilers, vehicles and elsewhere. \\
\hline Scope 2 & $\begin{array}{l}\text { Indirect emissions arise from purchased electricity in } \\
\text { company-owned/controlled equipment. } \\
\text { Emissions occur at the facility where electricity is } \\
\text { generated. }\end{array}$ & Purchased electricity. \\
\hline Scope 3 & $\begin{array}{l}\text { Indirect emissions are an optional reporting category } \\
\text { because activities of the company occur around sources } \\
\text { not owned or controlled by the company. }\end{array}$ & $\begin{array}{l}\text { Extraction and production of purchased materials, } \\
\text { use of bought products, transportation of } \\
\text { purchased fuels and services. }\end{array}$ \\
\hline
\end{tabular}

Source: (WBCSD, 2011)

Direct emissions (Scope One), constituting up to $90 \%$ of the industry total, arise from facilities owned or controlled by the company, caused by burning fossil fuels like coal and industrial diesel oil (IDO), calcination, and on-site transportation (WBCSD, 2011; Hong et al., 2015). Net emissions are calculated as direct emissions minus those from AF usage (Feiz et al., 2015; Hong et al., 2015; Dietz, 2017). The WBCSD have provided data and means for calculations of direct emissions in cement production, as seen in Table 2. 


\section{ENTREPRENEURSHIP AND SUSTAINABILITY ISSUES}

ISSN 2345-0282 (online) http://jssidoi.org/jesi/ 2020 Volume 8 Number 1 (September) http://doi.org/10.9770/jesi.2020.8.1(7)

Table 1. Guidelines for calculation of direct $\mathrm{CO}_{2}$ emissions from the cement industry

\begin{tabular}{|c|c|c|c|}
\hline Emission components & Parameter & Unit & Proposed source of parameters \\
\hline \multicolumn{4}{|c|}{$\mathrm{CO}_{2}$ from raw materials: Methods based on clinker output } \\
\hline \multirow{2}{*}{$\begin{array}{l}\text { Calcination of raw material for } \\
\text { clinker production }\end{array}$} & Clinker produced & tons & Measured at the plant level \\
\hline & Emission factor clinker & $\mathrm{t} \mathrm{CO}_{2} / \mathrm{t}$ clinker & $\begin{array}{l}\text { Default }=0.525 \text { (CSI-WBCSD); } \\
\text { or as calculated in detailed output } \\
\text { method }\end{array}$ \\
\hline \multirow[t]{3}{*}{ Calcination of dust } & Dust leaving kiln system & tons & Measured at the plant level \\
\hline & Emission factor clinker & $\mathrm{t} \mathrm{CO}_{2} / \mathrm{t}$ clinker & Measured at the plant level \\
\hline & Dust calcination degree & $\%$ & Measured at the plant level \\
\hline \multirow[t]{3}{*}{ Organic carbon in raw materials } & Clinker produced & tons & Measured at the plant level \\
\hline & Raw meal: clinker & fraction $\mathrm{t} / \mathrm{t}$ clinker & Default $=1.55 ;$ can be adjusted \\
\hline & TOC content of the raw meal & mass fraction & Default $=0.2 \% ;$ can be adjusted \\
\hline \multicolumn{4}{|c|}{$\mathrm{CO}_{2}$ from kiln and non-kiln combustion } \\
\hline \multirow[t]{3}{*}{ Conventional fuels } & Fuel consumption & tons & Measured at the plant level \\
\hline & Lower heating value & GJ /t fuel & Measured at the plant level \\
\hline & Emission factor & $\mathrm{t} \mathrm{CO}_{2} / \mathrm{GJ}$ fuel & IPCC/CSI defaults or measured \\
\hline \multirow{4}{*}{$\begin{array}{l}\text { Alternative fossil fuels and mixed } \\
\text { fuels }\end{array}$} & Fuel consumption & tons & Measured at the plant level \\
\hline & Lower heating value & GJ /t fuel & Measured at the plant level \\
\hline & Emission factor & $\mathrm{t} \mathrm{CO}_{2} / \mathrm{GJ}$ fuel & CSI defaults or measured \\
\hline & Biogenic carbon content & mass fraction & $\begin{array}{l}\text { CSI defaults or measured at the } \\
\text { plant level }\end{array}$ \\
\hline \multirow[t]{3}{*}{ Biomass fuels } & Fuel consumption & tons & Measured at the plant level \\
\hline & Lower heating value & $\mathrm{GJ} / \mathrm{t}$ fuel & Measured at the plant level \\
\hline & Emission factor & $\mathrm{t} \mathrm{CO}_{2} / \mathrm{GJ}$ fuel & IPCC/CSI defaults or measured \\
\hline Wastewater combusted & - & - & Quantification of $\mathrm{CO}_{2}$ not required \\
\hline
\end{tabular}

Source: (WBCSD, 2011; Perindustrian, 2014)

Note: AFs = Alternative Fuels, TOC $=$ Total Organic Carbon

Indirect (Scope Two) emissions are generated from operating activities undertaken or controlled by other entities. They are not significant compared with the direct variety. Based on the WBSCD Protocol, companies are asked to monitor their direct emission intensity. Under the Kyoto Protocol of 2009, non- $\mathrm{CO}_{2}$ emissions from cement production are ignored because they are not dominant (WBCSD, 2011; Andrew, 2018).

\subsection{Key Indicators for a Sustainable Cement Industry}

The collaboration of the CSI-WBCSD and IEA has established key indicators to enable moves towards sustainability in global cement production (Table 3). They serve as guidelines for companies to plan for future operations. Of concern are activities which can support the achievement of SDS (sustainable development scenario) emission intensity targets of $0.55 \mathrm{t} \mathrm{CO}_{2} \mathrm{e} / \mathrm{t}$ by 2030 . Meanwhile, the average emission intensity in the industry globally is around $0.7 \mathrm{t} \mathrm{CO}_{2} \mathrm{e} / \mathrm{t}$ cement (Bakhtyar et al., 2017).

Table 2. Indicators for Sustainability Goals in the Global Cement Industry

\begin{tabular}{|l|c|}
\hline \multicolumn{1}{|c|}{ Indicator } & SDS Target in 2030 \\
\hline Emission Intensity (Direct Emission) (t CO 2 e/t cement) & 0.55 \\
\hline Clinker to Cement Ratio & 0.64 \\
\hline Electricity intensity (kWh/t cement) & 87 \\
\hline Alternative fuels use (\% of thermal energy) & 18 \\
\hline Thermal energy intensity of clinker (GJ/t clinker) & 3.3 \\
\hline
\end{tabular}

Source: (IEA, 2018) 


\section{The Case Study}

The case study was carried out at the premier cement group in Indonesia. It has four integrated production plants and uses a dry process. On average, the clinker-making kilns operate 24 hours a day for between 330 to 340 days annually, while the other production equipment, such as the crusher, grinder and mill, run around 220 days per annum. We start by reviewing direct and indirect emission performance and profiles before turning to the need for international benchmarking.

\subsection{Direct Emissions (Scope 1)}

\subsubsection{Calcination}

Calcination occurs when limestone is subjected to hot gas at $1500^{\circ} \mathrm{C}$ in a kiln, generally referred as pyroprocessing. Limestone, which is basically calcium carbonate $\left(\mathrm{CaCO}_{3}\right)$, decomposes into calcium oxide (lime) $(\mathrm{CaO})$ and carbon dioxide $\left(\mathrm{CO}_{2}\right)$. This chemical process produces most of the $\mathrm{CO}_{2}$ emissions involved in clinker production and that of the final product, cement (Ali et al., 2011; Stafford et al., 2016).

Therefore, the CSI-WBSCD recommends using clinker data rather than final cement production data in calculations. It follows that estimating the clinker fraction in cement to calculate clinker production can be undertaken only if cement data are available (WBCSD, 2011).

The method for estimating $\mathrm{CO}_{2}$ emissions from clinker production employs the equation (WBCSD, 2011; Damayanti \& Lestari, 2013; Energy, 2017; Andrew, 2018):

In which:

$$
\mathbf{E}_{\text {clc }}=\left(\mathbf{E F}_{\text {clc }}+\mathbf{E F}_{\text {toc }}\right) \times\left(\mathbf{Q}_{\text {clc }}+\left(\mathbf{Q}_{\text {ckd }} \mathbf{x} \mathbf{F}_{\text {ckd }}\right)\right)
$$

$\mathrm{E}_{\text {clc }}$ is the $\mathrm{CO}_{2}$ emission released from the production of clinker $\left(\mathrm{CO}_{2} \mathrm{e}\right.$ tons $)$.

$\mathrm{EF}_{\mathrm{clc}}$ is the emission factor for clinker $\left(0.525 \mathrm{t} \mathrm{CO}_{2} \mathrm{e} / \mathrm{t}\right.$ clinker $)$.

$\mathrm{EF}_{\text {toc }}$ is the emission factor for carbon-bearing non-fuel raw material $\left(0.01 \mathrm{t} \mathrm{CO}_{2} \mathrm{e} / \mathrm{t}\right.$ clinker produced).

$\mathrm{Q}_{\mathrm{clc}}$ is the quantity of cement clinker produced (tons).

$\mathrm{Q}_{\mathrm{ckd}}$ is the quantity of cement kiln dust (CKD) produced (tons).

$\mathrm{F}_{\mathrm{ckd}}$ is the degree of calcination of cement kiln dust. If the information is not available, the degree is assumed to be $100 \%$, such that $\mathrm{F}_{\mathrm{ckd}}=1$.

Based on production data from 2017, the subject company produced 10,534,385 tons of clinker and CKD. Its GHG emissions from the calcination process reached 5,635,896 $\mathrm{t} \mathrm{CO}_{2} \mathrm{e}$.

\subsubsection{Kiln and Non-Kiln Fuels}

In the direct manufacturing situation studied, the primary source of energy is coal, with usage of 2,364,077 t/year, which collectively accounts for $98 \%$ of Scope One energy consumption (Figure 3). Since high-grade Indonesian thermal coal is routinely exported, low-calorie $(\leq 4200 \mathrm{kcal} / \mathrm{kg})$ lignite is used in kilns with a usage index of $0.22 \mathrm{t}$ coal/t clinker. The required thermal energy to produce clinker is $3.3 \mathrm{GJ} / \mathrm{t}$ clinker. It can be noted though, that, per unit weight, lignite combustion produces less pollution due to its calorific value and carbon component (25\%$35 \%)$ which are lower than those of high-grade coal such as anthracite (86\%-97\%) (EIA, 2018). 


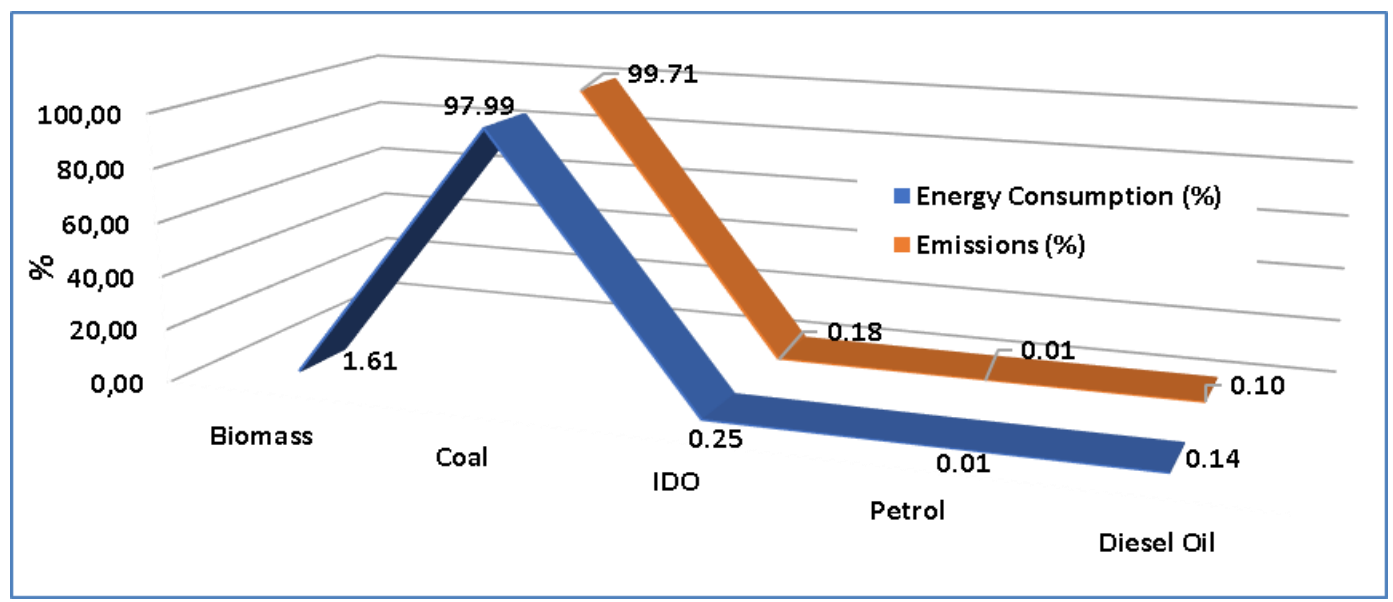

Fig. 2. Energy consumption and emissions by sources in the company studied, 2017

The company has also begun to use biomass as an AF, though only in limited quantities. According to the guidelines, reporting of emissions from AFs must be carried out separately, and emission factors for those such as biomass are absent (WBCSD, 2011). Emissions generated from the energy sources currently in use at the plants equal 3,754,822 $\mathrm{t} \mathrm{CO}_{2} \mathrm{e}$, well below that of the chemical process producing calcination. Thus, the total direct emissions (Scope One) emanating from calcination and energy for non-kiln and kiln use equal 9,390,718 t $\mathrm{CO}_{2} \mathrm{e}$.

\subsection{Indirect Emissions (Scope 2)}

The indirect emissions calculated at the sites relate to electricity purchased from the state electricity company. Consumption in the year under study totaled 1,270,981 MWh, consisting of power for cement production and for supporting ancillary equipment (e.g. offices, lighting). Electricity is used in equipment such as the crusher, grinder, kiln and packer.

Based on the corporate analysis, the average electricity index was $93.7 \mathrm{kWh} / \mathrm{t}$ cement, whereas global electricity relativities are estimated from 91-130 kWh/t (Olivier et al., 2017; IEA, 2018). The indirect emissions generated from the recorded electricity usage amounted to 1,095,586 $\mathrm{t} \mathrm{CO}_{2} \mathrm{e}$, with the emission factor reaching $0.862 \mathrm{t}$ $\mathrm{CO}_{2} \mathrm{e} / \mathrm{MWh}(\mathrm{JCM}, 2017)$.

\subsection{Emission Profiles}

The total GHGs from direct (Scope One) and indirect emissions (Scope Two) from the company in 2017 were $10,486,303 \mathrm{t} \mathrm{CO}_{2} \mathrm{e}$. Of this volume, the chemical reaction in calcination is the leading emitter with $53.7 \%$ of the total, followed by the combustion of coal in the kiln at $35.7 \%$, and electricity at $10.4 \%$ (Figure 4 ). 


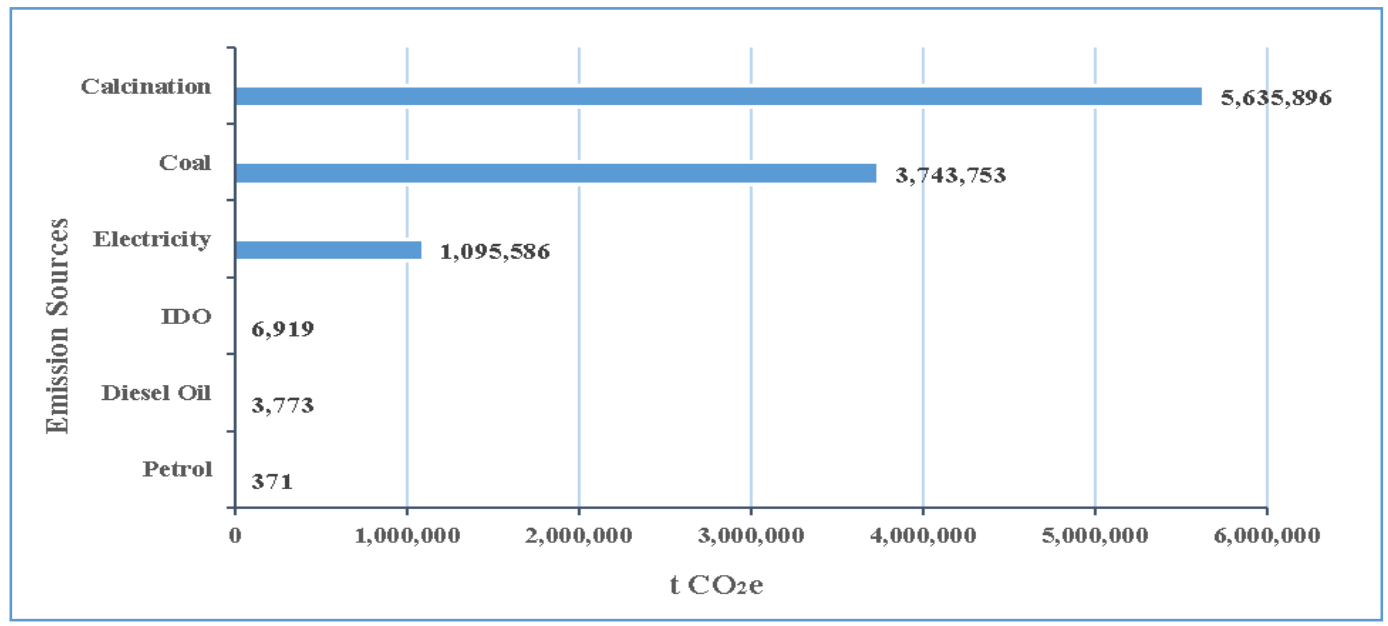

Fig. 3. Emissions (tons of $\mathrm{CO}_{2}$ ) by sources in the cement company studied, 2017

The direct emission intensity is $0.696 \mathrm{t} \mathrm{CO}_{2} \mathrm{e} / \mathrm{t}$ cement, higher than the SDS target of $0.55 \mathrm{t} \mathrm{CO}_{2} \mathrm{e} / \mathrm{t}$. Meanwhile, the indirect emission intensity (Scope Two) from the company remains at a reasonable level. The firm is planning to utilize waste heat from the combustion in the kilns during calcination via a Waste Heat Recovery Power Generator (WHRPG) with a capacity of $30.6 \mathrm{MW}$. It should lower electricity supplied by outside parties by 165 million $\mathrm{kWh}$ annually. This reduction promises savings of up to IDR 120 billion (US $\$ 8.5$ billion) and will curtail emissions by $122,000-150,000$ t CO$_{2} \mathrm{e} /$ year (Indonesia, 2018b). The indirect emissions intensity (Scope Two) will fall from 0.08 to $0.07 \mathrm{t} \mathrm{CO}_{2} \mathrm{e} / \mathrm{t}$ cement.

\subsection{Benchmarking}

In order to establish the environmental performance benchmarks of different firms, the data used as indicators must be clearly defined. They help to analyze the gap between the company studied and world best practices. For its part, the firm can determine priority actions for emission abatement projection based on the indicators. This step must be followed by considering possible resources at the local level, along with conditions which support and hinder implementation.

At present, the Indonesian firm's ratio of clinker to cement (or the clinker factor) is 0.8 , higher than the global average of 0.77 (Schneider et al., 2011). World best practice is posted by Switzerland's LafargeHolcim and Brazil's Intercement at 0.73 . Furthermore, the Indonesian enterprise's use of AF is very much lower, at around $1.2 \%$, when compared with Mexico's Cemex (26.2\%), Germany's Heidelberg (21\%), Switzerland's LafargeHolcim (16.5\%) and Thailand's Siam Cement (11\%) (Figure 5). 


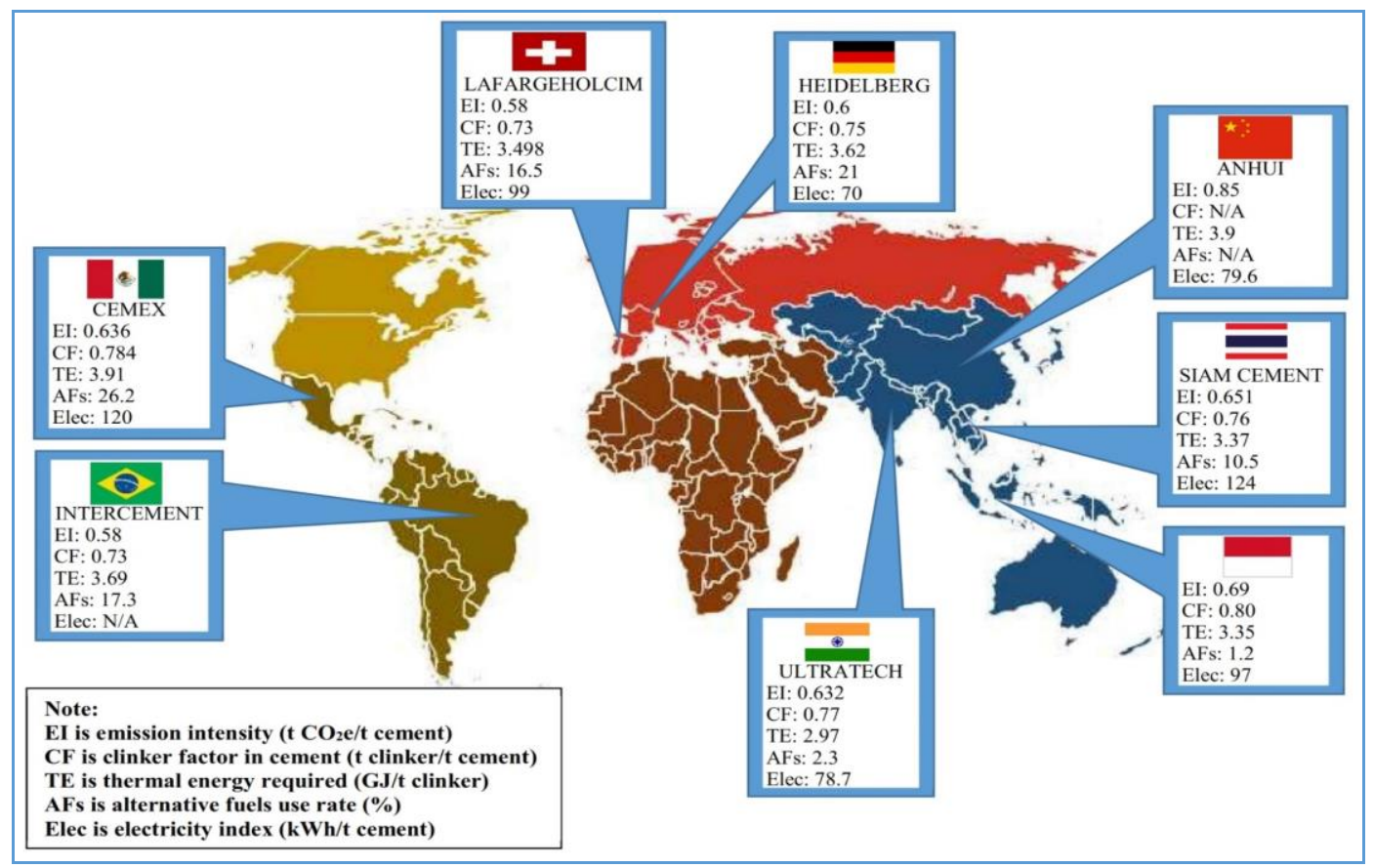

Fig. 4. Overview of Environmental Performance in the Global Cement Industry in 2017

Source: (Limited, 2017; SCG, 2017; Cemex, 2018; Conch, 2018; Heidelberg, 2018; Intercement, 2018; LafargeHolcim, 2018)

\subsection{Abatement Projection}

Reduction plans in the company should focus on lowering the ratio of clinker to cement, utilization of AFs and decreasing the thermal energy intensity of clinker (Figure 6).

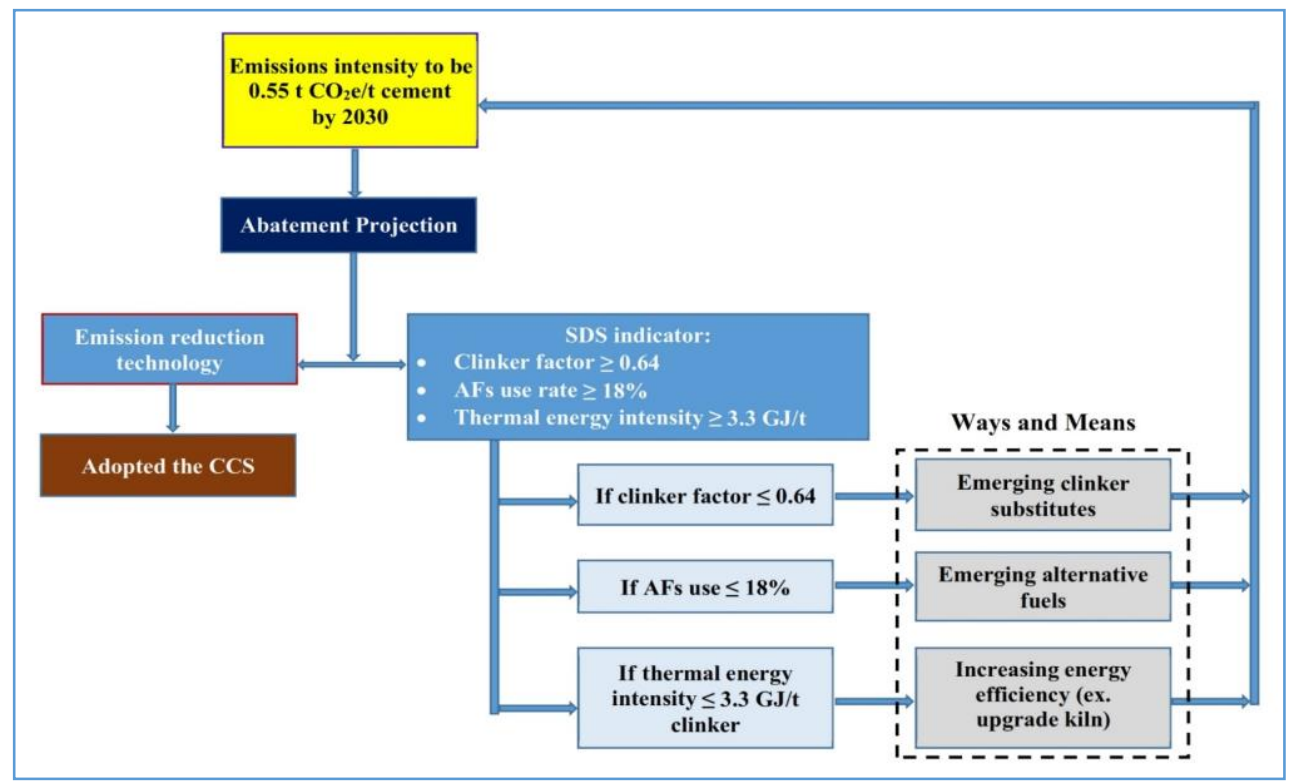

Fig. 5. Schematic diagram for identifying abatement projections Source: (Chowaniec, 2012; Galvez-Martos \& Schoenberger, 2014) 


\section{ENTREPRENEURSHIP AND SUSTAINABILITY ISSUES}

ISSN 2345-0282 (online) http://jssidoi.org/jesi/

2020 Volume 8 Number 1 (September)

http://doi.org/10.9770/jesi.2020.8.1(7)

\subsubsection{Reduction of Clinker/Cement Ratio}

The substitution of limestone for 10-12\% of the composition of the final output does not decrease the quality of cement or concrete robustness. However, beyond that ratio, it can weaken the product and so increase the quantity needed to obtain the specific engineering strength expected (Mohammadi \& South, 2016; Scrivener et al., 2018).

To meet the SDS target, operators must increase the number of clinker replacements which will reduce the clinker/cement ratio and emission intensity. Besides limestone, fly ash is used as a clinker substitute. Around the world, the absorption of substitutes has risen from 5 to 35\% of the composition of cement (Chowaniec, 2012; Gao et al., 2015). Fly ash is a fine powder derived from waste generated from burning coal in power stations and factories. It contains silica oxide $\left(\mathrm{SiO}_{2}\right)$, aluminum $\left(\mathrm{Al}_{2} \mathrm{O}_{3}\right)$, iron $\left(\mathrm{Fe}_{2} \mathrm{O}_{3}\right)$, and calcium oxide $(\mathrm{CaO})$. It can reduce water needed and increase concrete strength (Chousidis et al., 2015; Mengxiao et al., 2015).

Fly ash remains in limited use in the case study company. Its use could rise due to its availability throughout Indonesia, mainly from burning coal in power generation. Nationally, the installed electricity capacity is 59,600 MW. Around $70 \%$ of plants are steam powered and consume coal with the capacity to produce up to 10 million tons of fly ash per year (Jayaranjan et al., 2014; Notonegoro, 2018). Even so, much is discarded in landfill because of restrictive government regulations (Irawan, 2018). Policies, especially public ones, which support manufacturers to utilize waste, are needed. They can reduce negative impacts, such as pollution and costs in handling.

Utilization of clinker replacement materials in the company will potentially reduce emissions by $0.91 \mathrm{t} \mathrm{CO}_{2} \mathrm{e} / \mathrm{t}$ clinker subtitute, due to lowered emissions from chemical processes in calcination and constraints in coal usage. It is equivalent to cutting emissions by $930,000 \mathrm{t} \mathrm{CO}_{2} \mathrm{e} /$ year for every $10 \%$ increase in the clinker substitute. The use of substitutes such as fly ash, furnace slag, trass (soft rock or soil from volcanic ash), and limestone is the most economical, effective, and easily accessible way to overcome emissions (CEMBUREAU, 2012; Gao et al., 2015). These materials, in general, can be added directly to cement to increase its volume and reduce solid waste, and they do not require pyroprocessing. Such steps can save a significant amount of energy and emissions (CEMBUREAU, 2012; Chowaniec, 2012).

\subsubsection{Alternative Fuels (AFs)}

Non-renewable fuels such as liquid natural gas (LNG) and industrial diesel oil (IDO) have a lower carbon content than coal. However, utilization of the former is not possible in the situations studied because of the absence of pipeline infrastructure. IDO is possible but economically infeasible owing to high operational costs (UNFCCC, 2011). Therefore, it is necessary to find AF sources which avoid significant obstacles involving availability and price. Cement companies in many countries have started reducing GHGs through using, as the primary agents, refuse-derived fuel (RDF) from industrial and municipal solid waste (MSW), and biomass (Kara, 2012; Hong et al., 2018).

The company studied has also begun to use RDF from MSW as an alternative fuel. RDF is abundant in many developed countries. In 2015, its utilization rate (mainly from tires, and commercial and industrial waste) reached 39\% in Europe, compared with Indonesia which recorded under 2\% (Hong et al., 2018; Indonesia, 2018a). In Indonesia, MSW is also abundant -- in 2017 around 66 million tons (Prastowo, 2012; Ridlo, 2014; BPS, 2018). It has a high-calorie value, superior to lignite, ranging from 5,100-5,200 kcal/kg due to plastic, paper and biomass (Ummatin et al., 2017; BPS, 2018). Yet, managing MSW is still a major challenge facing many developing countries. Indonesia's population of more than 260 million notwithstanding, budget constraints limit the availability of adequate waste treatment facilities (BPS, 2018). The use of RDF as an AF is expected not only to impact economically because of lower costs, but also to assist in handling MSW (Genon \& Brizio, 2008; BPS, 


\section{ENTREPRENEURSHIP AND SUSTAINABILITY ISSUES}

ISSN 2345-0282 (online) http://jssidoi.org/jesi/ 2020 Volume 8 Number 1 (September) http://doi.org/10.9770/jesi.2020.8.1(7)

2018; Farizal et al., 2018; Hong et al., 2018). The downside could be the larger amounts of heavy metals in the waste gas, so the quality and the quantity of RDF should be carefully analysed (Genon \& Brizio, 2008). Utilization of one ton of RDF in the company studied could reduce coal consumption by 1.44 tons and emissions by $2.3 \mathrm{t} \mathrm{CO}_{2} \mathrm{e}$. Scaled up, 164,000 tons of RDF could replace $10 \%$ of coal use during a year and reduce emissions by $374,372.5 \mathrm{t} \mathrm{CO}_{2} \mathrm{e}$.

Biomass is widely available in developing countries (Rahman et al., 2014; Brunerová et al., 2018) and, as an AF in Indonesia, can produce energy of around 756 million GJ/year. This capacity consists of 614.6 million GJ/year from agricultural residues or crops, and 141.5 million GJ/year from forest waste (Prastowo, 2012; Ummatin et al., 2017). Biomass from rice husk has been taken in by the firm. In 2017, 45,070 tons generated 575,599 GJ of energy. It led to a reduction of emissions equivalent to $96,434 \mathrm{t} \mathrm{CO}_{2} \mathrm{e}$. Additionally, ash from burning rice husk can be used as a pozzolanic material because it has a high silica content, and is also a potential substitute for clinker (Kumar et al., 2013; Singh, 2018). However, it tends to be financially unviable because it requires complex processes such as grinding to a very fine particle size, contributing to air pollution and an increase in emissions. It further requires controlled combustion (Rahman et al., 2014).

The biomass from agricultural sources such as rice husk, palm shells, and coconut fiber generally comes from rural areas. Rice husk has considerable potential, the annual availability of $66,411,469$ tons equivalent to approximately 369 million GJ/year or 60\% of the total energy from crops in Indonesia (Prastowo, 2012; Ummatin et al., 2017). The rice husk resource within $200 \mathrm{~km}$ from the cement plants studied amounts to 867,625 t/year. Of it, at least 563,957 t/year is available within less than $75 \mathrm{~km}$ (UNFCCC, 2011). The $\mathrm{CO}_{2} \mathrm{e}$ emission reduction in rice husk tonnage to replace coal isequivalent to $0.97 \mathrm{t} \mathrm{CO}_{2} \mathrm{e} / \mathrm{t}$ biomass, with a calorific value of approximately $12.771 \mathrm{GJ} / \mathrm{t}$ (UNFCCC, 2011; Anshar et al., 2016), in some instances approaching that of lignite but beneficially derived from renewable sources. It has the potential to lower the use of lignite by up to $750,000 \mathrm{t} / \mathrm{year}$, equal to reducing emissions by approximately $1,200,000 \mathrm{t} \mathrm{CO}_{2} \mathrm{e} /$ year.

Although the cost of purchasing AFs is less than that of fossil fuels (and can even be free), their utilization will require expenses for installation and transportation. These materials, in general, need additional processing before they can be engaged, such as separating, drying, crushing/shredding and mixing (Chinyama, 2011; Deolalkar, 2016). Given several different AFs, companies tend to avoid installing excessive handling and feed equipment. Therefore, cement plants generally only use one or two types (Deolalkar, 2016). It is necessary to look for suitable AFs which are widely available at economical prices.

AF utilization will likely encounter obstacles due to a lack of support from regulations, policies, public acceptance, infrastructure and technical capabilities (Hasanbeigi et al., 2012). Emerging economies such as Indonesia need to learn from developed partners in drafting legislation and standards which can encourage usage, followed by an audit and an initiative to convince the local community of the advantages of using AF from waste. Government support is needed, such as in providing infrastructure, subsidies in waste management, tax incentives and other financial assistance. Since the characteristics of waste in various places or countries can be different, it is necessary to map types and availability. This step can help to determine the right technology.

\subsubsection{Plant Technology Improvement}

Efforts to reduce the intensity of heat and electricity consumption in cement production focus on updating kiln technology, responsible for the most energy-consuming calcination processes (Smidth, 2006; IEA, 2009; Madlool et al., 2011). Means to limit waste and emissions follow the best available technology (BAT) approach. BAT for kilns currently uses a five or six-stage pre-heating technology with a pre-calciner (Figure 7). It can achieve a thermal energy consumption of 2.9-3.1 GJ/t clinker, significantly below the global target (IEA, 2018). Such CCS technology can also offer notable emission reductions. However, it is still in its early stages and has not been 
widely implemented (Jordal et al., 2017; Nabernegg et al., 2017; Olivier et al., 2017).

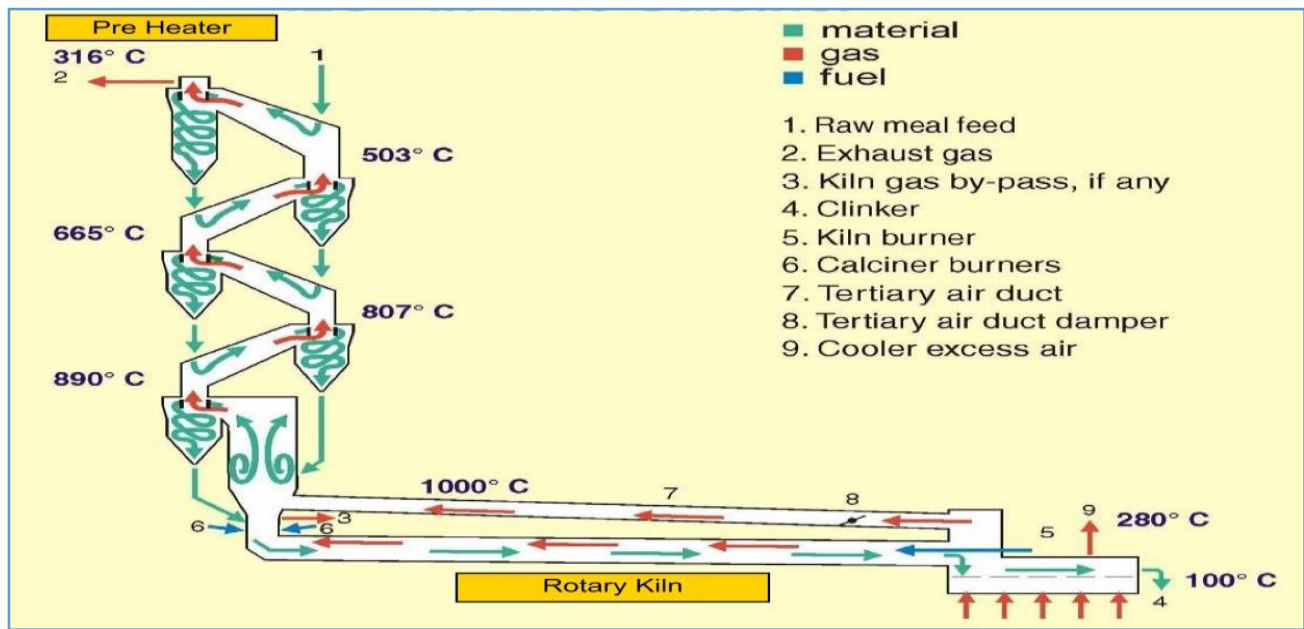

Fig. 6. Five pre-heaters kiln with pre-calciner Source: Adapted from (Smidth, 2006)

The company studied uses kilns with a four-stage pre-heater with a pre-calciner. The average thermal energy requirement has reached the 2030 SDS target. Upgrading from four-stage preheating with a pre-calciner to five stages can reduce heat consumption by $6 \%$ or $0.2 \mathrm{GJ} / \mathrm{t}$ clinker, cutting emissions by $225,000 \mathrm{t} \mathrm{CO}_{2} \mathrm{e} /$ year. Six stages can post up to $12 \%$ falls or $0.4 \mathrm{GJ} / \mathrm{t}$ clinker, offering reductions of $445,000 \mathrm{t} \mathrm{CO}_{2} \mathrm{e} / \mathrm{year}$. The capital cost to upgrade pre-heating from four to five stages, or five to six stages, is at least US\$2.54/t clinker. It will increase the production cost index of cement by $2.5 \%$ to five stages, or $5 \%$ to six stages (Table 4 ).

Table 4. Heat consumption and cost for kiln technologies

\begin{tabular}{|c|c|c|c|c|}
\hline Process & $\begin{array}{c}\text { Fuel use } \\
\text { (GJ/t clinker) }\end{array}$ & $\begin{array}{c}\text { Energy } \\
\text { Reductions }\end{array}$ & $\begin{array}{c}\text { Cost } \\
\text { (US\$/year ton clinker) }\end{array}$ & Ref \\
\hline Wet process & $5.9-6.7$ & - & - & \multirow{2}{*}{$\begin{array}{l}\text { (Smidth, 2006; IEA, 2009; Madlool et al., } \\
\text { 2011; Worrell et al., 2013) }\end{array}$} \\
\hline Dry process & 4.6 & $22-31 \%$ & $50-100$ & \\
\hline - 1-stage pre-heater & 4.2 & $29-37 \%$ & $68-118$ & \multirow{4}{*}{$\begin{array}{l}\text { (Smidth, 2006; IEA, 2009; Hasanbeigi et } \\
\text { al., 2010b; Madlool et al., 2011; Worrell } \\
\text { et al., 2013) }\end{array}$} \\
\hline - 2-stage pre-heater & 3.8 & $36-43 \%$ & $70.5-120.5$ & \\
\hline - 4-stage pre-heater & 3.3 & $44-51 \%$ & $85-135$ & \\
\hline $\begin{array}{l}\text { - 4-stage pre-heater }+ \\
\text { pre-calciner }\end{array}$ & 3.1 & $47-55 \%$ & $103-148$ & \\
\hline $\begin{array}{l}\text { - 5-stage pre-heater }+ \\
\text { pre-calciner }\end{array}$ & $3.0-3.1$ & $49-54 \%$ & $105.5-150.5$ & \multirow{2}{*}{$\begin{array}{l}\text { (Smidth, 2006; IEA, 2009; Price et al., } \\
\text { 2009; Hasanbeigi et al., 2010b; Madlool } \\
\text { et al., 2011; Worrell et al., 2013) }\end{array}$} \\
\hline $\begin{array}{l}\text { - 6-stage pre-heater + } \\
\text { pre-calciner }\end{array}$ & 2.9 & $51-57 \%$ & $158-157.5$ & \\
\hline
\end{tabular}

The high investment costs and complexity in changing the pre-heater structure within existing process engineering can hamper implementation (Price et al., 2009). Conventional economic policies such as providing broad manufacturing energy price subsidies can also restrain technological progress, as currently observed in Indonesia. They can prevent uptake of more efficient technology by key industry players (Summerbell et al., 2016). 


\section{ENTREPRENEURSHIP AND SUSTAINABILITY ISSUES}

ISSN 2345-0282 (online) http://jssidoi.org/jesi/ 2020 Volume 8 Number 1 (September) http://doi.org/10.9770/jesi.2020.8.1(7)

\section{Conclusions}

At the cement operation studied, nearly $78 \%$ of total energy consumption comes from direct (Scope One, inplant) coal and fuel oil burning, followed by (Scope Two) imported electricity at 22\%. Emissions from calcination account for $53.7 \%$ of the total, coal utilization for $35.7 \%$, electricity $10 \%$, and the rest from fuel oil. The direct emission intensity is around $0.69 \mathrm{t} \mathrm{CO}_{2} \mathrm{e} / \mathrm{t}$ cement. The company needs to reduce this figure by $20 \%$ to meet the global target of $0.55 \mathrm{t} \mathrm{CO}_{2} \mathrm{e} / \mathrm{t}$ cement by 2030 , equivalent in its case to $1,969,892 \mathrm{t} \mathrm{CO}_{2} \mathrm{e}$.

This inquiry analyzed measures which have the potential to drive such emission reductions. Following both the "low-hanging fruit" rule in project management and the rational choice model of economics, the ones adopted should center first on processes that create the most accessible emissions, namely, calcination and coal combustion. They are interrelated; calcination is a clinker formation process that requires heat from coal combustion. The firm's ratio of clinker to cement is currently 0.8 or $25 \%$ higher than the global SDS indicator for 2030. The use of AFs is still less than 2\%, while the global aim is $18 \%$ by 2030 .

Fulfilling its objectives, this paper has identified three ways in which the Indonesian cement industry can move towards world best practice.

- First, the use of clinker substitutes such as limestone and fly ash reduces direct emissions from two primary sources at once, namely, from the chemical reaction in calcination and from energy use. The cost of procuring clinker substitutes is generally less than orthodox clinker production because the material is mostly in the form of waste and involves savings in raw materials, electricity and fuels. Utilization of clinker replacement materials by $10 \%$ can reduce the emissions intensity by $11 \%$, a positive elasticity.

- Second, the use of AFs such as RDF and biomass, all to hand in the country, can support conservation, increase income, and reduce negative impacts on the environment and local communities. Utilization of biomass in the plant can reduce emissions intensity by $13 \%$.

- Third, improving kiln technology: adopting five stages can reduce emissions intensity by $2.4 \%$ and six stages by $4.8 \%$. Refurbishing entails significant investment costs and technical complexity.

The first two options above provide opportunities to achieve global targets for emissions intensity in 2030. Besides being able to reduce absolute emissions significantly, they can also increase product competitiveness, conserve non-renewable resources, and lower raw materials uptake and waste disposal. However, in keeping with an emerging economy, cost constraints and lack of supporting public policy can block implementation. Financial assistance from the government is needed, such as subsidies in waste management and tax incentives. Also required are policies which support other parties to utilize waste and improve technical capabilities in adopting appropriate technology.

From, all these investigations, the present analysis is able to provide recommendations for the national cement industry in choosing emission reduction measures. It is expected to help other countries which have similar conditions to those of Indonesia. The findings are both timely and spatially opportune, since nations which have significant sources of clinker substitute materials and AFs are spread throughout Southeast Asia and the developing world. 


\section{ENTREPRENEURSHIP AND SUSTAINABILITY ISSUES}

ISSN 2345-0282 (online) http://jssidoi.org/jesi/ 2020 Volume 8 Number 1 (September) http://doi.org/10.9770/jesi.2020.8.1(7)

\section{References}

Afkhami, B., Akbarian, B., Beheshti A, N., Kakaee, A. H., \& Shabani, B. (2015). Energy consumption assessment in a cement production plant. Sustainable Energy Technologies and Assessments, 10, 84-89. http://dx.doi.org/10.1016/j.seta.2015.03.003

Ali, M. B., Saidur, R., \& Hossain, M. S. (2011). A review on emission analysis in cement industries. Renewable and Sustainable Energy Reviews, 15(5), 2252-2261. https://doi.org/10.1016/j.rser.2011.02.014

Andrew, R. M. (2018). Global CO 2 emissions from cement production. Earth System Science Data, 10(1), $195-217$. https://doi.org/10.5194/essd-10-195-2018

Anshar, M., Ani, F. N., \& Kader, A. S. (2016). Electrical energy potential of rice husk as fuel for power generation in Indonesia. ARPN Journal of Engineering and Applied Sciences, 11(6), 3616-3624. http://doi.org/10.4028/www.scientific.net/AMR.845.494

Bakhtyar, B., Kacemi, T., \& Nawaz, M. A. (2017). A review on carbon emissions in Malaysian cement industry. International Journal of Energy Economics and Policy, 7(3), 282-286. https://doaj.org/article/48b033ee32a34caa82470221390953f5

Board, E. (2019). Dominance in cement market. The Jakarta Post. Retrieved from https://www.thejakartapost.com/academia/2019/02/20/dominance-in-cement-market.html.

BPPT. (2016). Outlook energi Indonesia 2016: Energy development in supporting geen industry. Jakarta, Indonesia: The Agency for the Assessment and Application of Technology.

BPS. (2018). Pengelolaan sampah di Indonesia - Statistik Lingkungan Hidup Indonesia 2018 (Waste management in Indonesia-Indonesia environmental statistics 2018). Badan Pusat Statistik Indonesia (Central Bureau of Statistics) Retrieved from https://www.bps.go.id/publication/download.html?nrbvfeve=ZDhjYmI1NDY1YmQxZDMxMzhjMjFmYzgw\&xzmn=aHR0cH M6Ly93d3cuYnBzLmdvLmlkL3B1YmxpY2F0aW9uLzIwMTgvMTIvMDcvZDhjYmI1NDY1YmQxZDMxMzhjMjFmYzgwL3 N0YXRpc3Rpay1saW5na3VuZ2FuLWhpZHVwLWluZG9uZXNpYS0yMDE4Lmh0bWw\%3D\&twoadfnoarfeauf=MjAyMC0w Mi0xMiAxMDoxMDoxMg\%3D\%3D.

Brunerová, A., Roubík, H., Brožek, M., \& Velebil, J. (2018). Agricultural residues in Indonesia and Vietnam and their potential for direct combustion: with a focus on fruit processing and plantation crops. Agronomy Research, 16(3), 656-668. https://doi.org/10.15159/AR.18.113

Burritt, R. L., Schaltegger, S., \& Zvezdov, D. (2011). Carbon management accounting: explaining practice in leading German companies. Australian Accounting Review, 21(1), 80-98. https://doi.org/10.1111/j.1835-2561.2010.00121.x

CEMBUREAU. (2012). Cements for a low-carbon Europe A review of the diverse solutions applied by the European cement industry through clinker substitution to reducing the carbon footprint of cement and concrete in Europe Retrieved from https://cembureau.eu/media/1501/cembureau cementslowcarboneurope.pdf

Cemex. (2018). Integrated report. Retrieved from San Pedro: https://www.cemex.com/documents/20143/0/IntegratedReport2017.pdf/.

Chinyama, M. P. (2011). Alternative fuels in cement manufacturing. Alternative fuel, 263-284. Retrieved from https://www.intechopen.com/books/alternative-fuel/alternative-fuels-in-cement-manufacturing

Chousidis, N., Rakanta, E., Ioannou, I., \& Batis, G. (2015). Mechanical properties and durability performance of reinforced concrete containing fly ash. Construction and Building Materials, 101, 810-817. http://dx.doi.org/10.1016/j.conbuildmat.2015.10.127

Chowaniec, O. (2012). Limestone addition in cement. (PhD), EPFL, Switzerland. Retrieved from http://infoscience.epfl.ch/record/174700/files/EPFL_TH5335.pdf

Conch, A. (2018). 2017 social responsibility report. Retrieved from http://iis.quamnet.com/media/IRAnnouncement/914/EN_US/003082858-0.PDF

Damayanti, S., \& Lestari, P. (2013). Inventarisasi emisi CO2 dari proses kalsinasi pada industri semen di Indonesia berdasarkan IPCC Guidelines 2006 (Inventory of CO2 emissions from the calcination process in the cement industry in Indonesia based on the 2006 


\section{ENTREPRENEURSHIP AND SUSTAINABILITY ISSUES}

ISSN 2345-0282 (online) http://jssidoi.org/jesi/ 2020 Volume 8 Number 1 (September) http://doi.org/10.9770/jesi.2020.8.1(7)
IPCC
guidelines).
Retrieved
from
Bandung:
http://publikasi.ftsl.itb.ac.id/assets/repositori/2013 $10 \quad 19 / 2 / 1 \quad 2 \quad 15309001$ berkas.pdf

Dasih, K., \& Widodo, T. (2019). Indonesia's commitment to reducing GHG and its impact on the Indonesian economy: CGE approach. Munich: University Library of Munich.

Deolalkar, S. P. (2016). Feasibility of using alternative fuels in cement kilns. In S. P. Deolalkar (Ed.), Designing Green Cement Plants (pp. 79-82): Butterworth-Heinemann.

Dietz, S., French, E., \& Jackson, P. (2017). Carbon performance assessment of cement producers: Note on methodology Retrieved from http://www.lse.ac.uk/GranthamInstitute/tpi/wp-content/uploads/2017/09/Methodology-note-for-cement-8-Aug.pdf

EIA. (2018). Coal explained. Energy Information Administration. Retrieved from https://www.eia.gov/energyexplained/print.php?page=coal_prices

Energy, D. o. t. E. a. (2017). National greenhouse accounts factors: Australian national greenhouse accounts. Australian Government: Department of the Environment and Energy Retrieved from https://www.environment.gov.au/system/files/resources/5a169bfbf417-4b00-9b70-6ba328ea8671/files/national-greenhouse-accounts-factors-july-2017.pdf.

Farizal, F., Aji, R., Rachman, A., Nasruddin, N., \& Mahlia, T. M. I. (2018). Indonesia's municipal solid waste 3R and waste to energy programs. Makara Journal of Technology, 21(3), 153-159. http://doi:10.7454/mst.v21i3.3536

Feiz, R., Ammenberg, J., Baas, L., Eklund, M., Helgstrand, A., \& Marshall, R. (2015). Improving the CO2 performance of cement, part I: utilizing life-cycle assessment and key performance indicators to assess development within the cement industry. Journal of Cleaner Production, 98, 272-281. https://doi.org/10.1016/j.jclepro.2014.01.083

Galvez-Martos, J.-L., \& Schoenberger, H. (2014). An analysis of the use of life cycle assessment for waste co-incineration in cement kilns. Resources, Conservation and Recycling, 86, 118-131. http://dx.doi.org/10.1016/j.resconrec.2014.02.009

Gao, T., Shen, L., Shen, M., Chen, F., Liu, L., \& Gao, L. (2015). Analysis on differences of carbon dioxide emission from cement production and their major determinants. Journal of Cleaner Production, 103, 160-170. https://doi.org/10.1016/j.jclepro.2014.11.026

Geng, Y., Sarkis, J., \& Bleischwitz, R. (2019). How to globalize the circular economy. Nature, 565(7738), 153-155. http://doi.org/10.1038/d41586-019-00017-Z

Genon, G., \& Brizio, E. (2008). Perspectives and limits for cement kilns as a destination for RDF. Waste Management, 28(11). http://10.1016/j.wasman.2007.10.022

Grubler, A. (2012). Energy transitions research: Insights and cautionary tales. Energy Policy, 50, 8-16. http://doi.org/10.1016/j.enpol.2012.02.070

Haraguchi, N., Cheng, C. F. C., \& Smeets, E. (2017). The Importance of manufacturing in economic development: Has this changed? World Development, 93, 293-315. https://doi.org/10.1016/j.worlddev.2016.12.013

Haryadi, H., \& Suciyanti, M. (2018). Analisi perkiraan kebutuhan batubara untuk industri domestik tahun 2020-2035 dalam endukung kebijakan domestik market obligation dan kebijakan energi nasional (Analysis of coal needs estimation for domestic industries in 2020-2035 for supporting domestic market obligation policy and national energy policy). Jurnal Teknologi Mineral dan Batubara (Journal of Mineral and Coal Technology 2018), 14(1), 59-73. http://doi.org/10.30556/jtmb.Vol14.No1.2018.192

Haryanto, J. T., \& Martawardaya, B. (2015). Kodifikasi dan efektivitas kebijakan fiskal untuk menurunkan emisi gas rumah kaca pada industri semen, baja dan pulp (Codification and effectiveness of fiscal policy to reduce greenhouse gas emissions in the cement, steel and pulp industries). Jurnal Ilmu Sosial dan Ilmu Politik (Journal of Social Sciences and Political Sciences), 19(1), 78-97. https://doi.org/10.22146/jsp.13040

Hasanbeigi, A., Menke, C., \& Therdyothin, A. (2010a). The use of conservation supply curves in energy policy and economic analysis: the case study of Thai cement industry. Energy Policy, 38(1), 392-405. https://doi.org/10.1016/j.enpol.2009.09.030 


\section{ENTREPRENEURSHIP AND SUSTAINABILITY ISSUES}

ISSN 2345-0282 (online) http://jssidoi.org/jesi/ 2020 Volume 8 Number 1 (September) http://doi.org/10.9770/jesi.2020.8.1(7)

Hasanbeigi, A., Price, L., \& Lin, E. (2012). Emerging energy-efficiency and CO2 emission-reduction technologies for cement and concrete production: A technical review. Renewable and Sustainable Energy Reviews, 16(8), 6220-6238. https://doi.org/10.1016/j.rser.2012.07.01

Hasanbeigi, A., Price, L., Lu, H., \& Lan, W. (2010b). Analysis of energy-efficiency opportunities for the cement industry in Shandong Province, China: A case study of 16 cement plants. Energy, 35(8), 3461-3473. http://doi.org/10.1016/j.energy.2010.04.046

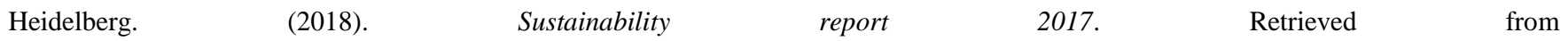
https://www.heidelbergcement.com/en/system/files force/assets/document/37/e0/heidelbergcement-sustainability-report$\underline{\text { 2017.pdf }}$

Hong, G.-B., Huang, C.-F., Lin, H.-C., \& Pan, T.-C. (2018). Strategies for the utilization of alternative fuels in the cement industry. Carbon Management, 9(1), 95-103. https://doi.org/10.1080/17583004.2017.1409044

Hong, G.-B., Ma, C.-M., Hsiao, C.-C., \& Chang, C.-T. (2015). A case study of greenhouse gas inventory and mitigation measures in the cement industry of Taiwan. Carbon Management, 6(3-4), 141-150. http://doi.org/10.1080/17583004.2015.1090316

IEA. (2009). Energy technology transitions for industry: strategies for the next industrial revolution Retrieved from https://www.iea.org/publications/freepublications/publication/industry2009.pdf

$\begin{array}{llllr}\text { IEA. } & \text { (2017). } & \text { Energy } & \text { efficiency } & \text { Retrieved }\end{array}$ http://www.iea.org/publications/freepublications/publication/Energy_Efficiency_2017.pdf

IEA. (2018). Cement Retrieved from https://www.iea.org/tcep/industry/cement/

Iizuka, M. (2015). Diverse and uneven pathways towards transition to low carbon development: the case of solar PV technology in China. Innovation and Development, 5(2), 241-261. http://dx.doi.org/10.1080/2157930X.2015.1049850

Iklim, D. N. P. (2010). Indonesia's greenhouse gas abatement cost curve (pp. 56). Retrieved from http://www.dnpi.go.id/report/DNPIMedia-Kit/reports/indonesia-ghg_abatement_cost_curve/Indonesia_ghg_cost_curve_english.pdf

Indonesia, S. (2018a). Enhancing tomorow S. R. 2017 (Ed.) Retrieved from https://semenindonesia.com/wpcontent/uploads/2018/04/SR_SMI_2017_1904.pdf

Indonesia, S. (2018b). WHRPG "green electricity" from http://jcm.ekon.go.id/en/uploads/files/Document\%20JCM/Presentation/Workshop\%20on\%20Joint\%20Crediting\%20Mechanism \%20(JCM)\%20\%20Accelerating\%20Private\%20Sector\%20Participation\%20towards\%20LowCarbon\%20Development\%20in\%20Indonesia/7._PT_Semen_Indonesia___Good_Practice_Sharing_WHRPG_Tuban_Plant.pdf

Intercement. (2018). Annual report, 2017. Retrieved from Sao Paulo: http://www.intercement.com/sites/ra2017/en/.

Irawan, R. R. (2018). Penggunaan abu batu bara dalam beton untuk infrastruktur. Retrieved from http://iasiitenas.com/2018/08/16/penggunaan-abu-batu-bara-dalam-beton-untuk-infrastruktur/

Janssens-Maenhout, G., Guizzardi, D., Muntean, M., Schaaf, E., Olivier, J. G. J., Peters, J. A. H. W., et al. (2017). Fossil CO2 and GHG emissions of all world countries: Luxembourg: Publications Office.

Jayaranjan, M. L. D., Van Hullebusch, E. D., \& Annachhatre, A. P. (2014). Reuse options for coal fired power plant bottom ash and fly ash. Reviews in Environmental Science and Bio/Technology, 13(4), 467-486. http://doi.org/10.1007/s11157-014-9336-4

JCM. (2017, Oct 08. 2018). Faktor emisi. Retrieved from http://jcm.ekon.go.id/id/index.php/content/Mzg\%253D/faktor_emisi

Jordal, K., Voldsund, M., Størset, S., Fleiger, K., Ruppert, J., Spörl, R., et al. (2017). CEMCAP-making CO2 capture retrofittable to cement plants. Energy Procedia, 114, 6175-6180. http://doi.org/10.1016/j.egypro.2017.03.1755

Kara, M. (2012). Environmental and economic advantages associated with the use of RDF in cement kilns. Resources, Conservation and Recycling, 68, 21-28. http://doi.org/10.1016/j.resconrec.2012.06.011 


\section{ENTREPRENEURSHIP AND SUSTAINABILITY ISSUES}

ISSN 2345-0282 (online) http://jssidoi.org/jesi/ 2020 Volume 8 Number 1 (September) http://doi.org/10.9770/jesi.2020.8.1(7)

Ke, J., Zheng, N., Fridley, D., Price, L., \& Zhou, N. (2012). Potential energy savings and CO2 emissions reduction of China's cement industry. Energy Policy, 45, 739-751. http://dx.doi.org/10.1016/j.enpol.2012.03.036

Kumar, S., Sangwan, P., Dhankhar, R. M. V., \& Bidra, S. (2013). Utilization of rice husk and their ash: A review. Res. J. Chem. Env. Sci, $1(5), 126-129$.

$\begin{array}{llllll}\text { LafargeHolcim. } & \text { (2018). } & \text { Sustainability } & \text { report } & 2017 . & \text { Retrieved }\end{array}$ https://www.lafargeholcim.com/sites/lafargeholcim.com/files/atoms/files/04062018_lafargeholcim-sustainability-report-2017.pdf

Limited, U. $\quad$ C. (2017). Building a sustainable future. https://www.ultratechcement.com/common/images/downloads/UltraTech\%20Sustainability\%20Report\%202016-17.pdf

Madlool, N. A., Saidur, R., Hossain, M. S., \& Rahim, N. A. (2011). A critical review on energy use and savings in the cement industries. Renewable and Sustainable Energy Reviews, 15(4), 2042-2060. https://doi.org/10.1016/j.rser.2011.01.005

Mengxiao, S., Qiang, W., \& Zhikai, Z. (2015). Comparison of the properties between high-volume fly ash concrete and high-volume steel slag concrete under temperature matching curing condition. Construction and Building Materials, 98, 649-655. http://doi.org/10.1016/j.conbuildmat.2015.08.134

Mohammadi, I., \& South, W. (2016). General purpose cement with increased limestone content in Australia. (Technical Paper). ACI Materials Journal, 113(3), 335-347. http://doi.org/10.14359/51688703

Nabernegg, S., Bednar-Friedl, B., Wagner, F., Schinko, T., Cofala, J., \& Clement, Y. M. (2017). The Deployment of low carbon technologies in energy intensive industries: A macroeconomic analysis for Europe, China and India. Energies, 10(3), 1-26. http://doi.org/10.3390/en10030360

Notonegoro, K. (2018, 29 June 2018). Manfaat ekonomi penggunaan batubara untuk Listrik (Economic benefits of using coal for electricity). Investor Daily. Retrieved from https://id.beritasatu.com/home/manfaat-ekonomi-penggunaan-batubara-untuk$\underline{\text { listrik/177193 }}$

Okereke, C. (2007). An exploration of motivations, drivers and barriers to carbon management: The UK FTSE 100. European Management Journal, 25(6), 475-486. https://doi.org/10.1016/j.emj.2007.08.002

Olhoff, A., \& Christensen, J. M. (2018). Emissions gap report 2018 Retrieved from https://www.unenvironment.org/resources/emissionsgap-report-2018

Olivier, J. G., Schure, K., \& Peters, J. (2017). Trends in global CO2 and total greenhouse gas emissions: 2017 Report: PBL Netherlands Environmental Assessment Agency, The Hague. Retrieved from https://www.pbl.nl/en/publications/trends-in-global-co2-andtotal-greenhouse-gas-emissions-2017-report.

Panjaitan, T. W. S., Dargusch, P., Aziz, A. A., \& Wadley, D. (2018). Carbon management in an emissions-intensive industry in a developing economy: cement manufacturing in Indonesia. Case Studies in the Environment, 2(1), 1-9. https://doi.org/10.1525/cse.2017.000976

Perindustrian, K. (2014). Petunjuk teknis perhitungan dan pelaporan emisi $\mathrm{CO}_{2}$ industri semen (Technical guidelines for calculation and reporting of cement industrial $\mathrm{CO}_{2}$ emissions). Jakarta: Kementerian Perindustrian Republik Indonesia (The Ministry of Industry of the Republic of Indonesia).

Prastowo, B. (2012, Sep 26-27). Biomass resource in Indonesia: Indonesia's solid biomass energy potential. Paper presented at the Proceedings of the Indonesia-German Workshop and Seminar. Institute Technology of Bandung.

Price, L., Hasanbeigi, A., Lu, H., \& Lan, W. (2009). Analysis of energy-efficiency opportunities for the cement industry in Shandong Province, China (No. LBNL-2751E-Rev). Berkeley, CA: Lawrence Berkeley National Laboratory.

Rahman, M. M., Mostafiz, S. B., Paatero, J. V., \& Lahdelma, R. (2014). Extension of energy crops on surplus agricultural lands: A potentially viable option in developing countries while fossil fuel reserves are diminishing. Renewable and Sustainable Energy Reviews, 29, 108-119. http://dx.doi.org/10.1016/j.rser.2013.08.092 


\section{ENTREPRENEURSHIP AND SUSTAINABILITY ISSUES}

ISSN 2345-0282 (online) http://jssidoi.org/jesi/ 2020 Volume 8 Number 1 (September) http://doi.org/10.9770/jesi.2020.8.1(7)

Ridlo, R. (2014). Indonesia's mitigation potential project: energy sector IPCC Expert Meeting on Application of 2006 IPCC Guidelines to Other Areas. Sofia, Bulgaria.

SCG. (2017). Ready to sustainability. $\quad$ Reliver $\quad$ from https://www.scg.com/en/05sustainability_development/03_sustainability_report.html

Schneider, M., Romer, M., Tschudin, M., \& Bolio, H. (2011). Sustainable cement production—present and future. Cement and Concrete Research, 41(7), 642-650. http://dx.doi.org/10.1016/j.cemconres.2011.03.019

Scrivener, K. L., John, V. M., \& Gartner, E. M. (2018). Eco-efficient cements: Potential economically viable solutions for a low-CO2 cement-based materials industry. Cement and Concrete Research, 114, 2-26. https://doi.org/10.1016/j.cemconres.2018.03.015

Singh, B. (2018). 13 - Rice husk ash. In R. Siddique \& P. Cachim (Eds.), Waste and Supplementary Cementitious Materials in Concrete (pp. 417-460): Woodhead Publishing.

Smidth, F. L. (2006, Aug 28). Cement plant pyro technology. Paper presented at the Presentation to the IEA -WBCSD Workshop on Energy Efficiency and CO Emission Reduction Potentials and Policies in the Cement Industry, Paris.

Society, S. E. (2012). Greenhouse gases: Specification with guidance at the organization level for quantification and reporting of greenhouse gas emissions and removals. London: British Standards Institution (BSI).

Stafford, F. N., Dias, A. C., Arroja, L., Labrincha, J. A., \& Hotza, D. (2016). Life cycle assessment of the production of Portland cement: a Southern Europe case study. Journal of Cleaner Production, 126, 159-165. http://dx.doi.org/10.1016/j.jclepro.2016.02.110

Summerbell, D. L., Barlow, C. Y., \& Cullen, J. M. (2016). Potential reduction of carbon emissions by performance improvement: A cement industry case study. Journal of Cleaner Production, 135, 1327-1339. doi:https://doi.org/10.1016/j.jclepro.2016.06.155

Tsitsiragos, D. (2016). Climate change is a threat - and an opportunity - for the private sector [Press release]. Retrieved from http://www.worldbank.org/en/news/opinion/2016/01/13/climate-change-is-a-threat---and-an-opportunity---for-the-private-sector

Ummatin, K. K., Yakin, D. A., \& MOA, Q. A. (2017). Analisa manfaat biaya proyek pembaharuan unit pengelolaan unit pengolahan sampah kota Gresik dengan teknologi hydrothermal (Project cost benefit analysis renewal management unit of Gresik city waste processing unit with hydrothermal technology). Jurnal Industrial Servicess, 3(1), 234-239.

UNFCCC. (2011). Project 3726: Partial substitution of fossil fuels with biomass at Semen Gresik cement plant in Tuban. Retrieved from https://cdm.unfccc.int/Projects/DB/ERM-CVS1274361514.11/view.

Urbancova, H. (2013). Competitive advantage achievement through innovation and knowledge. Journal of Competitiveness, 5(1), 82-96. http://doi.org/10.7441/joc.2013.01.06

WBCSD-IEA. (2009). Cement technology roadmap 2009-Carbon emissions reductions up to 2050 Retrieved from http://wbcsdcement.org/pdf/technology/WBCSD-IEA_Cement\%20Roadmap.pdf.

WBCSD. (2011). CO2 accounting and reporting standard for the cement industry Retrieved from https://www.wbcsdcement.org/pdf/tf1_co2\%20protocol\%20v3.pdf

Williams, I., Kemp, S., Coello, J., Turner, D. A., \& Wright, L. A. (2012). A beginner's guide to carbon footprinting. Carbon Management, 3(1), 55-67. http://doi.org/10.4155/cmt.11.80

Worrell, E., Kermeli, K., \& Galitsky, C. (2013). Energy efficiency improvement and cost saving opportunities for cement making an ENERGY STAR ${ }^{\circledR}$ Guide for energy and plant managers. Retrieved from https://dspace.library.uu.nl/handle/1874/321366

Wright, L. A., Coello, J., Kemp, S., \& Williams, I. (2011). Carbon footprinting for climate change management in cities. Carbon Management, 2(1), 49-60. doi:http://doi.org/10.4155/cmt.10.41 


\section{ENTREPRENEURSHIP AND SUSTAINABILITY ISSUES}

ISSN 2345-0282 (online) http://jssidoi.org/jesi/ 2020 Volume 8 Number 1 (September) http://doi.org/10.9770/jesi.2020.8.1(7)

\section{Acknowledgements}

This research is supported by SEES, the University of Queensland and the Ministry of Research, Technology and Higher Education - Republic of Indonesia together with the Indonesian Endowment Fund for Education (LPDP) - Ministry of Finance - Republic of Indonesia under BUDI LN (2017-2020) for postgraduate study, Grant Agreement Number 20160822028916.

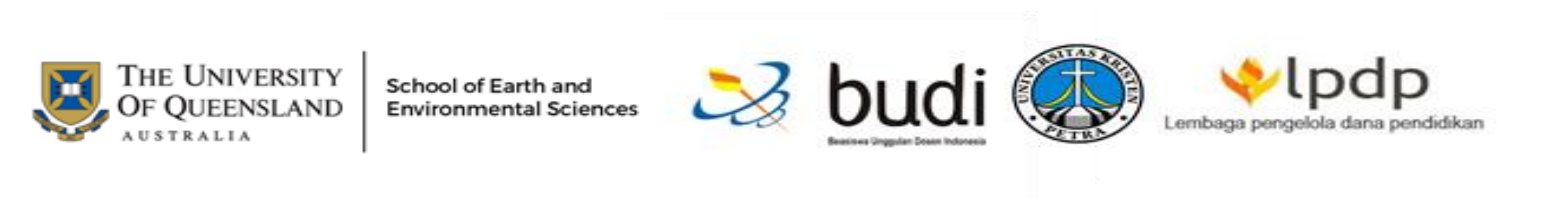

Togar W. S. PANJAITAN currently active as a PhD candidate at School of Earth and Environmetal Sciences, University of Queensland, Australia. He is as a lecturer at School of Industrial Business Engineering, Faculty of Industrial Technology, Petra Christian University, Indonesia. His research interest in environmental and energy management, sustainable transition and innovation.

ORCID ID: orcid.org/0000-0001-9698-2747

Paul DARGUSCH currently works as an Associate Professor in Environmental Management at The University of Queensland. His research interests cover various fields of environmental studies and environmental change, including tropical forest management, ecological engineering and restoration, energy economics and climate policy, and agricultural development. He has a special interest in environmental markets, particularly in how to achieve better returns from environmental finance.

ORCID ID: orcid.org/0000-0001-9255-2803

David WADLEY currently works as a senior lecturer at The University of Queensland. He received his PhD from the Australian National University in 1975. His research interests are in philosophy of planning and development, industrial and retail planning, economic geography and futurology.

ORCID ID: orcid.org/0000-0001-7768-4840

Ammar A. AZIZ is lecturer in agribusines at School of Agriculture and Food Sciences, Faculty of Science, University of Queensland, Australia. He received his PhD from the The University of Queensland. His research interests are in agribusiness, sustainable agriculture, remote sensing and spatial analysis.

ORCID ID: orcid.org/0000-0003-3470-2062

Register for an ORCID ID:

https://orcid.org/register

Copyright (C) 2020 by author(s) and VsI Entrepreneurship and Sustainability Center

This work is licensed under the Creative Commons Attribution International License (CC BY).

http://creativecommons.org/licenses/by/4.0/

C. (i) Open Access 